\title{
Chemical Composition and Anti-Inflammatory Evaluation of Essential Oils from Leaves and Stem Barks from Drimys brasiliensis Miers (Winteraceae)
}

\author{
João Henrique G. Lago, *,a Larissa A. C. Carvalho, ${ }^{b}$ Flávia S. da Silva, ${ }^{b}$ Daniela de O. Toyama, ${ }^{c}$ \\ Oriana A. Fávero ${ }^{c}$ and Paulete Romoff ${ }^{b}$
}

${ }^{a}$ Departamento de Ciências Exatas e da Terra, Universidade Federal de São Paulo, 09972-270 Diadema-SP, Brazil

${ }^{b}$ Centro de Ciências e Humanidades and ${ }^{c}$ Centro de Ciências Biológicas e da Saúde, Universidade Presbiteriana Mackenzie, 01302-907 São Paulo-SP, Brazil

\begin{abstract}
Os óleos essenciais das folhas e das cascas do tronco de Drimys brasiliensis Miers (Winteraceae) foram obtidos individualmente por hidrodestilação e suas composições químicas foram determinadas através de análise por CG/DIC e CG/EM. Os principais constituintes identificados foram monoterpenos (folhas $4,31 \%$ e cascas do tronco $90,02 \%$ ) e sesquiterpenos (folhas $52,31 \%$ e cascas do tronco 6,35\%). Adicionalmente, o sesquiterpeno poligodial foi isolado do extrato em hexano das cascas do tronco de $D$. brasiliensis após fracionamento cromatográfico e caracterizado por métodos espectroscópicos. Visando a avaliação do potencial anti-inflamatório, os óleos essenciais brutos e o sesquiterpeno poligodial foram submetidos à bioensaios para avaliação da toxicidade aguda destes compostos bem como das atividades anti-inflamatória e antinociceptiva induzidas por carragenina e formalina em ratos. Nossos resultados mostraram que o óleo essencial bruto obtido das cascas do tronco reduziu significativamente o edema induzido por carragenina. O efeito anti-inflamatório induzido pelo óleo das cascas do tronco (a $200 \mathrm{mg} \mathrm{kg}^{-1}$ ) foi similar ao observado para indometacina (a $10 \mathrm{mg} \mathrm{kg}^{-1}$ ) e superior ao poligodial (a $200 \mathrm{mg} \mathrm{kg}^{-1}$ ) em 30 e em 60 min após administração. A resposta inflamatória induzida pela formalina foi efetiva para o óleo das cascas do tronco $(62,5 \%)$ em comparação ao poligodial $(50,0 \%)$.
\end{abstract}

The essential oils from leaves and stem barks from Drimys brasiliensis Miers (Winteraceae) were individually obtained by hydrodistillation and their compounds characterized by use of GC/FID and GC/MS. The main identified derivatives were monoterpenes (leaves $4.31 \%$ and stem barks $90.02 \%$ ) and sesquiterpenes (leaves $52.31 \%$ and stem barks 6.35\%). Additionally, the sesquiterpene polygodial was isolated from hexane extract from stem barks of $D$. brasiliensis after chromatographic steps and characterized by spectroscopic means, mainly NMR. Aiming the evaluation of anti-inflammatory potential, the crude essential oils and the sesquiterpene polygodial were subjected to bioassays to evaluate the acute toxicity of these compounds as well as the anti-inflammatory and antinociceptive activities induced by carrageenan and formalin in mices. Ours results showed that essential oil obtained from the stem barks significantly reduced the oedema induced by carrageenan. The anti-inflammatory effect induced by stem barks oil (at $200 \mathrm{mg} \mathrm{kg}^{-1}$ ) was similar to observed for indomethacin (at $10 \mathrm{mg} \mathrm{kg}^{-1}$ ) and superior for polygodial (at $200 \mathrm{mg} \mathrm{kg}^{-1}$ ) in 30 and $60 \mathrm{~min}$ after the administration of essential oils. The inflammatory response induced by formalin was effective to the stem barks oil $(62.5 \%)$ in comparison to polygodial $(50.0 \%)$.

Keywords: Drimys brasiliensis Miers, essential oil composition, antinociceptive, antiinflammatory, acute toxicity

\section{Introduction}

Drimys brasiliensis Miers belongs to Winteraceae family, whose occurrence is restrict to South America. This

\footnotetext{
*e-mail: joao.lago@unifesp.br
}

species is known in Brazil with a vernacular name "cascad'anta" and has been used in folk medicine as analgesic and anti-inflammatory. ${ }^{1}$

In the chemical point of view, several species of Drimys have been shown to contain sesquiterpenes of drimane skeleton, which possess a variety of biological potential 
including antibacterial, ${ }^{2}$ anti-inflammatory, ${ }^{3}$ anti-allergic, ${ }^{3}$ antifungal ${ }^{4-6}$ antinociceptive, ${ }^{7-9}$ anti-hyperalgesic, ${ }^{10}$ and antibacterial. ${ }^{11}$ Nevertheless, there are only two works about the chemical composition of D. brasiliensis, in which the same type of drimane sesquiterpenes have been found, such as confertifolin, drimanial, valdiviolide, polygodial, $1-\beta-(p-$ methoxycinnamoyl)polygodial and 1- $\beta$-( $p$-cumaroyloxy) polygodial. ${ }^{6,12}$ The chemical composition of the essential oils from $D$. brasiliensis from Southern Brazil in different periods of collection has recently been described in the literature, ${ }^{13}$ in which the predominance of monoterpenes was observed in the leaves (fresh and dried) oils while the sesquiterpenes were the main derivatives in the stem bark and unripe fruits oils. Additionally, the both oils showed great amounts of cyclocolorenone, an unusual ketone-aromadendrane derivative, whose occurrence showed to be independent of the season in which the samples were collected. Despite of the use of infusions of bark from $D$. brasiliensis to the treatment of pain and ulcer, ${ }^{8}$ only the larvicidal potential of the volatiles against cattle tick Rhipicephalus (Boophilus) microplus and the brown $\operatorname{dog}$ tick $R$. sanguineus have been evaluated, which showed lethality in low concentrations. ${ }^{14}$

Therefore, in the course of our studies with pharmacologically active volatiles from Brazilian highland regions, ${ }^{15}$ we report here the chemical composition of the essential oils from leaves and stem barks from $D$. brasiliensis Miers (Winteraceae) as well as the evaluation of their anti-inflammatory potentials. Additionally, the biological activities of the crude oils were compared to that evaluated to sesquiterpene polygodial, which is the main constituent from the stem bark of Drimys species and responsible from the pharmacological effects for the extracts prepared from these plants. ${ }^{3,7,16,17}$ However, the potential observed to the analyzed oils could contribute to explain the popular use of bark infusion of $D$. brasiliensis to the pain treatment, since the components of the essential oils also showed anti-inflammatory effects.

\section{Experimental}

\section{Plant material}

Leaves and stem barks from Drimys brasiliensis Miers were collected in Umuarama district, Campos do Jordão, São Paulo, SP, in August 2006. Voucher specimen had been deposited at Herbarium of Prefeitura Municipal de São Paulo (PMSP) under number PMSP8984.

\section{Extraction of the essential oils}

Fresh leaves (115 g) and stem bark (902 g) from $D$. brasiliensis were individually subjected to hydrodistillation in a Clevenger type apparatus during $4 \mathrm{~h}$. After extraction, the essential oils were dried over anhydrous $\mathrm{Na}_{2} \mathrm{SO}_{4}$ and stored in sealed vials at low temperature. These procedures afforded $63 \mathrm{mg}(0.55 \%)$ from leaves oil and $1.624 \mathrm{mg}(0.18 \%)$ from stem barks oil. Chemical and biological studies of the obtained crude oils were performed immediately.

\section{General procedures}

Silica gel 60 (63-200 $\mu \mathrm{m}$, Merck) was used for adsorption chromatography and Sephadex LH-20 (Pharmacia) was used in exclusion chromatography. GC analysis were performed in a Hewlett-Packard 5890 series II chromatograph (using helium as carrier gas) equipped with a FID detector and a capillary column HP-5, cross linked $5 \%$ phenyl in $95 \%$ silicone $(30 \mathrm{~m} \times 0.32 \mathrm{~mm}$, I.D., $0.25 \mu \mathrm{m}$ film thickness), automatic injector (HP 7673) and electronic integrator (HP3396A). Temperature programming was performed as follows: $100{ }^{\circ} \mathrm{C}$ isothermal for $2 \mathrm{~min}$, $100-240{ }^{\circ} \mathrm{C}$ at $5{ }^{\circ} \mathrm{C} \mathrm{min}{ }^{-1}$, then isothermal at $240{ }^{\circ} \mathrm{C}$ for $10 \mathrm{~min}$. The injector and detector (FID) temperatures were established as $180{ }^{\circ} \mathrm{C}$ and $260{ }^{\circ} \mathrm{C}$, respectively. Component concentrations were calculated from GC peak areas in the order of HP-5 column elution $\left(\mathrm{RR}_{\mathrm{t}}\right.$ - retention time in seconds, as showed in Table 1). GC/MS analysis was carried out in a Shimadzu GC-17A chromatograph interfaced with a MS-QP-5050A mass spectrometer. Helium was used as the carried gas. The MS operating conditions were: ionization voltage $70 \mathrm{eV}$, ion source $230{ }^{\circ} \mathrm{C}$. The GC analysis was done with a DB-5 column (30 $\mathrm{m} \times 0.25 \mathrm{~mm}$ internal diameter, with $0.25 \mu \mathrm{m}$ film thickness) and the operating conditions were identical with those of the GC analysis. ${ }^{1} \mathrm{H}$ and ${ }^{13} \mathrm{C}$ NMR spectra were measured at 300 and $75 \mathrm{MHz}$, respectively, on a Bruker model DPX-300 spectrometer with sample dissolved in $\mathrm{CDCl}_{3}$ containing $1 \%$ of TMS (Aldrich). Formalin, carrageenan and indomethacin were purchased from Sigma Aldrich. Purity was assessed by HPLC and NMR as $>99 \%$. Unless stated otherwise, all other solvents were from Synth and Sigma.

\section{Compounds identification}

The crude oils were analyzed by GC and GC/MS. The identification of the components was based on the comparison o their mass spectra with those in the spectrometer data base (Willey 229 library) and confirmed by determination of their Kovats indexes (KI), which were determined relatively to the retention times of a series of $n$-alkanes. ${ }^{18}$ 
Table 1. Relative composition of the essential oils from the leaves and stem bark from Drimys brasiliensis

\begin{tabular}{|c|c|c|c|c|}
\hline \multirow[t]{2}{*}{$\mathrm{RR}_{\mathrm{t}} / \mathrm{s}$} & \multirow[t]{2}{*}{ RI DB-5 } & \multirow{2}{*}{$\begin{array}{l}\text { Volatile } \\
\text { components }\end{array}$} & \multicolumn{2}{|c|}{ Relative amount / \% } \\
\hline & & & leaves & stem bark \\
\hline 263 & 939 & $\alpha$-pinene & 1.64 & 39.50 \\
\hline 302 & 980 & $\beta$-pinene & 1.05 & 7.24 \\
\hline 317 & 991 & mircene & - & 4.83 \\
\hline 339 & 1011 & $\Delta^{3}$-carene & - & 5.65 \\
\hline 355 & 1031 & limonene & - & 4.94 \\
\hline 418 & 1088 & terpinolene & - & 9.02 \\
\hline 435 & 1117 & exo-fenchol & - & 1.07 \\
\hline 465 & 1143 & camphor & - & 0.58 \\
\hline 470 & 1148 & camphene hydrate & - & 0.65 \\
\hline 485 & 1165 & borneol & - & 0.77 \\
\hline 491 & 1177 & terpin-4-ol & 1.62 & 1.32 \\
\hline 496 & 1189 & $\alpha$-terpineol & - & 14.45 \\
\hline 652 & 1356 & eugenol & 1.21 & - \\
\hline 755 & 1409 & $\alpha$-cedrene & 6.87 & - \\
\hline 763 & 1480 & germacrene D & 4.74 & - \\
\hline 775 & 1494 & bicyclogermacrene & 5.31 & - \\
\hline 792 & 1538 & $\delta$-cadinene & 1.58 & - \\
\hline 813 & 1554 & elemicine & - & 0.77 \\
\hline 823 & 1564 & $E$-nerolidol & - & 2.86 \\
\hline 839 & 1576 & spathulenol & 3.34 & 1.48 \\
\hline 845 & 1583 & globulol & 3.33 & - \\
\hline 852 & 1590 & viridiflorol & 2.58 & - \\
\hline 885 & 1641 & $\tau$-muurolol & 7.75 & - \\
\hline 899 & 1653 & $\alpha$-cadinol & 4.83 & 1.32 \\
\hline 901 & 1673 & $\beta$-bisabolol & 2.13 & - \\
\hline 920 & 1674 & $E$-longipinocarveol & - & 0.69 \\
\hline 979 & 1759 & drimenol & 9.96 & - \\
\hline \multirow[t]{6}{*}{1090} & 1894 & rimuene & 5.96 & - \\
\hline & & Monoterpenes & 4.31 & 90.02 \\
\hline & & Sesquiterpenes & 52.31 & 6.35 \\
\hline & & Diterpene & 5.96 & - \\
\hline & & Phenylpropanoids & 1.21 & 0.77 \\
\hline & & TOTAL & 63.79 & 97.14 \\
\hline
\end{tabular}

\section{Isolation of polygodial from stem bark from D. brasiliensis}

Dried and powdered stem bark of D. brasiliensis $(687 \mathrm{~g})$ were exhaustively extracted with hexane $(6 \times 1000 \mathrm{~mL}$, $24 \mathrm{~h}$ each) to afford $8.72 \mathrm{~g}$ of hexane extract. Part of the crude extract $(6.0 \mathrm{~g})$ was subjected to silica gel column chromatography $(178 \mathrm{~g}, 40 \times 2 \mathrm{~cm})$ eluted with hexane containing increasing amounts of EtOAc (up to 100\%), to give nine fractions (1-9). Fraction 4 (4.1 g), eluted with hexane:EtOAc 8:2 (4.2 g) was purified using repeated Sephadex LH-20 (30 g, $20 \times 2 \mathrm{~cm})$ chromatographic procedures using $\mathrm{CH}_{2} \mathrm{Cl}_{2}: \mathrm{Me}_{2} \mathrm{CO}(3: 2)$ as solvent to afford 5 groups (I $-\mathrm{V})$. Colorless oil was obtained from group IV (3.0 g), which was analyzed by chromatographic (GC > 99\%) and spectroscopic methods (NMR and LREIMS). After comparison to literature data, ${ }^{19}$ this fraction showed to be composed by polygodial.

\section{Animals}

Female Swiss mices (25-30 g) were used throughout the experiments. The animals were supplied by the Centro Multidisciplinar para Investigação Biológica (Universidade Estadual de Campinas - UNICAMP). All the experiments were carried out with strict adherence to ethical guidelines. ${ }^{20}$

Acute toxicity $\left(L D_{50}\right)$

The acute toxicity in mice $(\mathrm{n}=5)$ was evaluated by intraperitoneal (i.p.) injection of crude oils/polygodial in different doses from 0.1 to $1.2 \mathrm{~g} \mathrm{~kg}^{-1}$, using DMSO $1 \%$ in saline solution $(\mathrm{NaCl}) 0.9 \%(\mathrm{~m} / \mathrm{v})$ for negative control. In this condition was observed that in concentration below of $0.5 \mathrm{~g} \mathrm{~kg}^{-1}$ no obits or effect were observed in the animal groups. Therefore, the concentration of $200 \mathrm{mg} \mathrm{kg}^{-1}$ was determined to evaluation of anti-inflammatory experiments. The effect and dead of animal were observed after $48 \mathrm{~h}$ of the drug administration. ${ }^{21}$

\section{Antinociceptive assay}

The formalin test was conducted as previosly described, ${ }^{22}$ with some minor modifications. Mices (vehicle and treated) were observed simultaneously for 0-30 min after intraplantar (i. pl.) injection of $20 \mu \mathrm{L}$ formalin solution $2.5 \%$ ( $0.92 \%$ formaldehyde, made up in saline solution $0.9 \%$ ) under the plantar surface of the right paw of mice. The time (in seconds) that the animals spent licking or lifting the injected paw was timed with a chronometer. The initial nociceptive response normally peaked about 0-10 min after formalin injection (first phase) and was followed by a second peak that occurred 15-30 min after formalin injection (second phase). ${ }^{22}$ Animals $(n=5)$ were pre-treated with the essential oils from leaves, stem bark and polygodial from $D$. brasiliensis (200 $\mathrm{mg} \mathrm{kg}^{-1}$ i.p.) one hour before formalin injection. Control animals received only vehicle (DMSO $1 \%$ in saline solution $0.9 \%$ ), which was used to dilute the essential oils and polygodial. Statistical analyses were made by ANOVA method. 


\section{Anti-inflammatory assay}

Carrageenan induced oedema assay was carried out according to Lima et al. ${ }^{23}$ Oedema was induced on the right hind foot of mice by intraplantar injection (i.pl.) of $20 \mu \mathrm{L}$ of a solution of $1 \%$ carrageenan in $0.9 \%$ saline solution $(\mathrm{NaCl}, \mathrm{m} / \mathrm{v})$. Local oedema was quantified by measuring the thickness of injected paws with a paquimeter at 30, 60, 90 and $180 \mathrm{~min}$ after injection. One hour before carrageenan injection, the animals $(n=5)$ were pre-treated with the essential oils from leaves and stem barks and polygodial obtained from D. brasiliensis (200 $\mathrm{mg} \mathrm{kg}^{-1}$ i.p.). Negative control animals received $50 \mu \mathrm{L}$ of vehicle (DMSO $1 \%$ in saline solution), which was used to dilute the essential oils and polygodial while the control positive group received $50 \mu \mathrm{L}$ the indomethacin (10 $\mathrm{mg} \mathrm{kg}^{-1}$ i.p.). Statistical analyses were made by ANOVA method.

\section{Results and Discussion}

The results for the chemical composition of the essential oils from leaves and stem barks from $D$. brasiliensis are shown in Table 1. A total of 28 volatile components were identified, accounting for $63.79 \%$ and $97.14 \%$ of the volatiles from leaves and stem bark oils, respectively. In the oil from leaves, composed by sixteen identified volatile derivatives, the sesquiterpenoids predominated $(52.31 \%)$, with $\alpha$-cedrene $(6.87 \%)$, bicyclogermacrene $(5.31 \%)$, $\tau$-muurolol $(7.75 \%)$ and drimenol $(9.96 \%)$ as the main derivatives (Figure 1). It is important mentioned that the

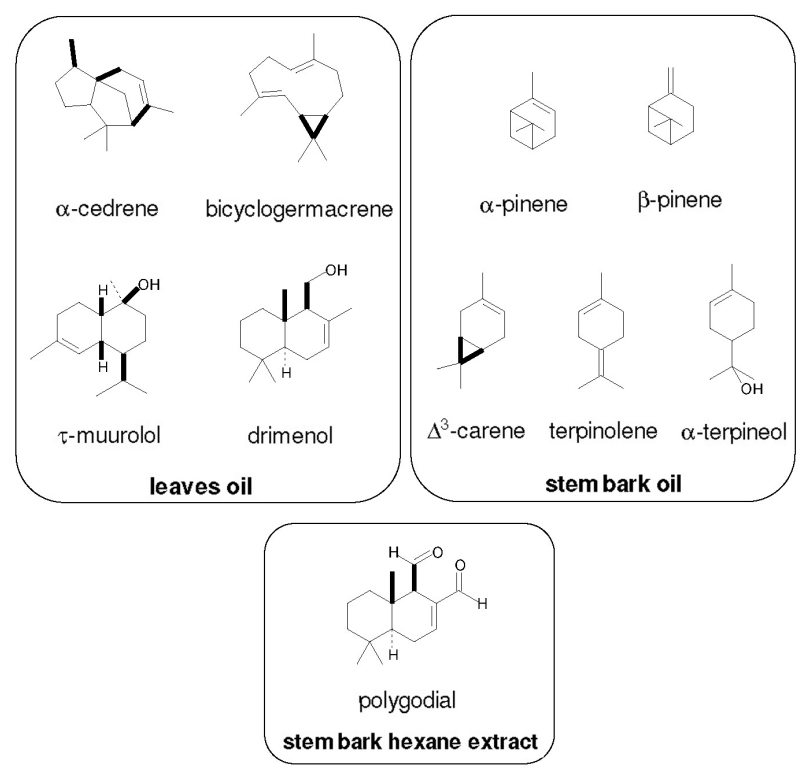

Figure 1. Structures of main derivatives identified in the essential oils from leaves and stem bark and polygodial isolated from hexane extract from stem bark of $D$. brasiliensis. occurrence of drimenol has been restrict to Winteraceae, Solanaceae and Polygonaceae species. ${ }^{13}$ Otherwise, seventeen constituents were identified from the stem barks oil with a high percentage of monoterpenes $(90.02 \%)$ being $\alpha$-pinene $(39.50 \%), \beta$-pinene $(7.24 \%), \Delta^{3}$-carene (5.65\%), terpinolene $(9.02 \%)$ and $\alpha$-terpineol $(14.45 \%)$ the most significant components in the monoterpene fraction (Figure 1).

Previous studies on volatile oils from $D$. brasiliensis, from the South region of Brazil (São Francisco de Paula $\mathrm{RS})$, showed that the main derivative was cyclocolorenone (16.0\% to $32.3 \%$ in the leaves and $46.7 \%$ to $49.7 \%$ in stem barks). ${ }^{13}$ However, as showed in Table 1, in the volatile oils analyzed in the present work ("Campos de Altitude" region), this compound was not detected. To confirm the absence of cyclocolorenone, the both oils were also submitted to ${ }^{1} \mathrm{H}$ and ${ }^{13} \mathrm{C}$ NMR spectral analysis, in which the characteristic signals from aromadendrane skeleton at approximately $\delta_{\mathrm{H}}$ 0.3-0.6 (H-6) / $\delta_{\mathrm{C}} 20.0(\mathrm{C}-11)$ were not observed. ${ }^{24,25}$ Although qualitative differences have been detected in the composition of the oils from $D$. brasiliensis, it is important mentioned that the sesquiterpenes were the main derivatives in the both oils from leaves. Otherwise, the comparison of the stem bark oils showed a complete difference in their composition, since in the present study were detected monoterpenes as major derivatives. Therefore, the detected chemical differences would be attributed to microclimatic conditions related to the different environments and geographic sites in which the plants grown. ${ }^{26}$ Additionally, the crude hexane extract from stem bark (8.72 g) was chromatographed over silica gel followed by filtration of Sephadex LH-20. After ${ }^{1} \mathrm{H}$ NMR analysis of all fractions obtained from fractionation procedures, the signals relative to aromadendrane skeleton were not observed, confirming the absence of cyclocolorenone in the analyzed species. Otherwise, was obtained a great amount $(3.0 \mathrm{~g}, 34.4 \%)$ of a pure compound whose ${ }^{1} \mathrm{H}$ NMR spectrum showed signals at $\delta 9.50(\mathrm{~d}, J 4.4 \mathrm{~Hz}, 1 \mathrm{H})$ and $9.43(\mathrm{~s}, 1 \mathrm{H})$, characteristic of aldehyde hydrogens. These data associated to the singlets at $\delta 0.90(3 \mathrm{H}), 0.92(3 \mathrm{H})$ and $0.93(3 \mathrm{H})$, as well as to $d d d$ at $\delta 7.12(J 7.5,2.2$ and $2.1 \mathrm{~Hz}, 1 \mathrm{H})$, showed to be characteristic of sesquiterpene polygodial. ${ }^{19}$ Finally, analysis of ${ }^{13} \mathrm{C}$ NMR spectrum, which showed peaks at $\mathrm{sp}^{2}$ carbons at $\delta 154.3$ (C-7), 138.3 (C-8), carbonyl carbons at $\delta 202.1$ (C-11), 193.2 (C-12), and methyl carbons at $\delta 33.1$ (C-13), 21.9 (C-14) and 15.2 (C-15) confirmed the proposal structure (Figure 1). ${ }^{19}$

Due to the occurrence of polygodial in the crude hexane extract from stem bark of $D$. brasiliensis associated to the different proportions of monoterpenes and sesquiterpenes in the essential oils from leaves and stem bark, the 
antinociceptive activity of these products was evaluated by induction for formalin in mice. ${ }^{22}$ As showed in Figure 2, the both essential oils (leaves and stem barks) did not inhibited neurogenic pain in the first phase of these experiments. However, the previous administration (60 min) of the crude essential oils and polygodial at $200 \mathrm{mg} \mathrm{kg}^{-1}$, reduced the second phase of nociception (inflammatory origin pain) in $25.0 \%$ (leaves oil), $62.5 \%$ (stem bark oil) and $50.0 \%$ (polygodial), as showed in Figure 2. The animals treated with vehicle (DMSO $1 \%$ in saline solution) lick or bite their paws during $250 \pm 10$ seconds in the second phase of this test $(\mathrm{p}<0.05, \mathrm{n}=5)$. Injection of formalin produced distinct biphasic responses being the first phase associated to the irritant effect of formalin in the $\mathrm{C}$ type sensorial fibers, which characterize the neurogenic pain. Otherwise, the second phase is associated to the inflammatory pain. Analgesics for central action, such as morphine, inhibit the both phases in contrast to drugs of peripheral action such as anti-inflammatories and corticoids, which inhibit only the second phase. ${ }^{22,27}$ Although polygodial has been described as antinociceptive and anti-inflammatory agent from $D$. winteri, ${ }^{10,17}$ the oil from stem barks of $D$. brasiliensis showed higher potential than this pure aldehyde sesquiterpene.

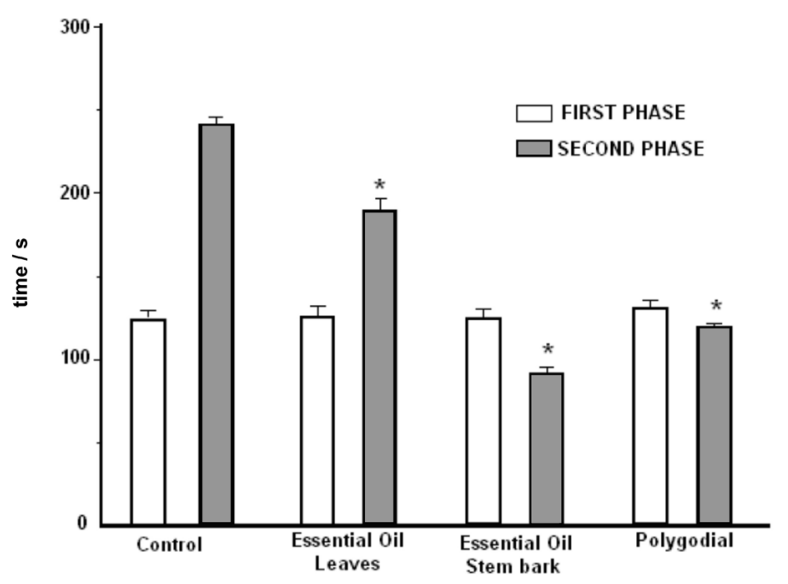

Figure 2. Effects of the essential oils from leaves and stem barks of $D$. brasiliensis on nociceptive responses to intraplantar injection of formalin (2.5\%). *P $<0.05$ compared to control (ANOVA).

Similarly, the inflammatory effect was induced by injection of carrageenan $1 \%$, which produced an oedema in the paw after $30 \mathrm{~min}(\mathrm{C}=3.8 \mathrm{~mm} ; \mathrm{n}=5) .{ }^{27,28}$ The previous administration (60 min) of the crude oil from stem barks from D. brasiliensis at $200 \mathrm{mg} \mathrm{kg}^{-1}$, showed an oedema reduction similar to the positive control indomethacin at $10 \mathrm{mg} \mathrm{kg}^{-1}$ but superior to that observed to pure polygodial at same concentration $\left(200 \mathrm{mg} \mathrm{kg}^{-1}\right)$ before $60 \mathrm{~min}$ of carrageenan administration (Figure 3). This result indicated that the volatile derivatives from stem bark showed antiedematogenic/anti-inflammatory proprieties due to reduction of acute oedema. The potent activity of the oil from stem bark might be attributed, at least in part, to its higher monoterpene content $(90.0 \%)$ in comparison to the leaves oil, mainly due the predominance of the monoterpene $\alpha$-pinene, which represent $39.5 \%$ of the oil content and showed anti-inflammatory effect. ${ }^{29}$ The experimental evidences showing that the crude oil from stem barks of D. brasiliensis showed pronounced anti-inflammatory proprieties when administered in mices. The obtained results were similar to those observed to sesquiterpene polygodial, an anti-inflammatory and antinociceptive agent obtained from the extract from stem barks of D. winter ${ }^{10}$ and D. brasiliensis. ${ }^{6}$

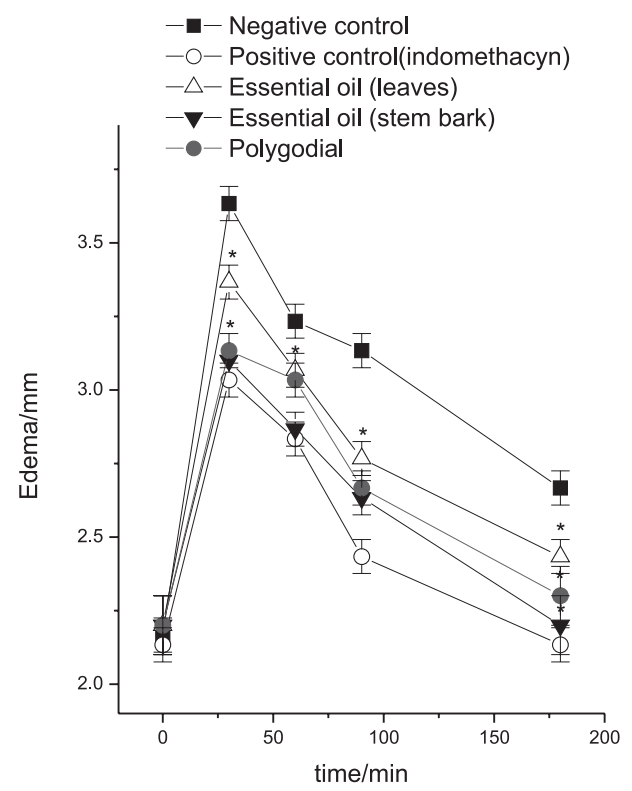

Figure 3. Effect of the essential oils (leaves and stem barks) and polygodial from $D$. brasiliensis on the development of oedema induced by intraplantar injection of carrageenan $1 \%$ in mice. ${ }^{*} \mathrm{P}<0.05$ compared to control (ANOVA).

\section{Conclusions}

The predominance of monoterpenes in the stem bark oil and sesquiterpenes in the leaves oil from $D$. brasiliensis collected in Campos do Jordão - SP indicated a different profile of that previously detected to oils from this specie, whose material was obtained from São Francisco de Paula - RS. This variation could be partially explained by different microclimatic factors in these regions as well as altitude, which affect the production of metabolites. ${ }^{26}$ These factors could explain also the absence of cyclocolorenone, which was suggested previously as a chemomarker of D. brasiliensis..$^{13}$ Analysis of the crude hexane extract afforded polygodial as major component and confirmed the absence of this ketone aromadendrane derivative. In 
a biological point of view, this study confirms the antiinflammatory proprieties of $D$. brasiliensis, which could be attributed not exclusively to polygodial, but at least in part, to the high proportion of monoterpenes in the volatile oils, mainly $\alpha$-pinene. It is important mentioned that this compound was detected in low amount in the no active essential oil obtained from the leaves from $D$. brasiliensis.

\section{Supplementary Information}

Supplementary data are available free of charge at http://jbcs.sbq.org.br, as PDF file.

\section{Acknowledgments}

Authors are thankful to FAPESP, MackPesquisa and CNPq for financial support and Prof. Dr. Marcos H. Toyama (UNESP-CLP) for donation of carrageenan.

\section{References}

1. Trinta E. F.; Santos E.; Winteráceas. Flora Ilustrada Catarinense; Herbário Barbosa Rodrigues: Itajaí, SC, Brasil, 1997.

2. Kubo, I.; Fujita, K. I.; Lee, S. H.; Ha, T. J.; Phytother. Res. 2005, 19, 1013.

3. Cunha, F. M.; Fröde, T. S.; Mendes, G. L.; Malheiros, A.; Cechinel Fo., V.; Yunes, R. A.; Calixto, J. B.; Life Sci. 2001, 70, 159.

4. Kubo, I.; Tanigushi, M.; J. Nat. Prod. 1988, 51, 22.

5. Kubo, I.; Fujita, K. I.; Lee, S. H.; J. Agric. Food Chem. 2001, 49, 1607.

6. Malheiros, A.; Cechinel Filho, V.; Schmitt, C. B.; Yunes, R. A.; Escalante, A.; Svetaz, L.; Zacchino, S.; Monache, F. D.; J. Pharm. Pharmac. Sci. 2005, 8, 335.

7. Malheiros, A.; Cechinel Fo., V.; Schimitt, C. B.; Santos, A. R. S.; Scheidt, C.; Calixto, J. B.; Monache, F. D.; Yunes, R. A.; Phytochemistry 2001, 57, 103.

8. Cechinel Fo., V.; Schlemper, V.; Santos, A. R. S.; Pinheiro, T. R.; Yunes, R. A.; Mendes, G. L.; Calixto, J. B.; Monache, F. D.; J. Ethnopharmacol. 1998, 62, 223.

9. Andre, E.; Ferreira, J.; Malheiros, A.; Yunes, R. A.; Calixto, J. B.; Neuropharmacology 2004, 46, 590.

10. Mendes, G. L.; Santos, A. R. S., Campos, M. M.; Tratsk, K. S.; Yunes, R. A.; Cechinel Fo., V.; Calixto, J. B.; Life Sci. 1998, $63,369$.
11. McCallion, R. F.; Cole, A. L. J.; Walker, J. R. L.; Blunt, J. W.; Munro, M. H. G.; J. Med. Plants Res. 1982, 44, 134.

12. Vichnewski, W.; Kulanthaivel, P.; Herz, W.; Phytochemistry 1986, $25,1476$.

13. Limberger, R. P.; Scopel, M.; Sobral, M.; Henriques, A. T.; Biochem. Syst. Ecol. 2007, 35, 130.

14. Ribeiro, V. L. S.; Rolim, V.; Bordignon, S.; Henriques, A. T.; Dorneles, G. G.; Limberger, R. P.; Poser, G. V.; Parasitol. Res. 2008, 102, 531.

15. Lago, J .H. G.; Romoff, P.; Fávero; Soares, M. G.; Baraldi, P. T.; Côrrea, A. G.; Souza, F. O.; Quim. Nova 2008, 31, 727.

16. Moreno-Osório, L.; Cortés, M.; Armstrong, V.; Bailén, M.; González-Coloma, A.; Z. Naturforsch. C 2008, 63c, 215.

17. Mendes, G. L.; Santos, A. R. S.; Malheiros, A.; Cechinel Filho, V.; Yunes, R. A.; Calixto, J. B.; J. Pharmacol. Exp. Ther. 2000, 292, 164.

18. Adams, R. P.; Identification of Essential Oil Components by Gas Chromatography/Quadrupole Mass Spectrometry; Allured Publishing Corporation: Illinois, 2001.

19. Rodriguez, B.; Zapata, N.; Medina, P.; Viñuela, E.; Magn. Reson. Chem. 2005, 43, 82.

20. Sherwin, C. M.; Christiansen, I. J.; Duncan, H. W. E.; Lay, J. D. C.; Mench, J. A.; O’Connor, C. E.; Petherick, J. C.; Appl. Anim. Behav. Sci. 2003, 8, 291.

21. Lorke, D.; Arch. Toxicol. 1983, 54, 275.

22. Hunskaar, S.; Fasmer, O. B.; Hole, K.; J. Neurosci. Meth. 1985, $14,69$.

23. Lima, C.; Clissa, B. P.; Piran-Soares, A. A.; Tanjoni, I.; Silva, A. M. M.; Ferreira, M. L.; Toxicon 2003, 42, 499.

24. Moreira, I. C.; Lago, J. H. G.; Young, M. C. M.; Roque N. F.; J. Braz. Chem. Soc. 2003, 14, 828.

25. Goldsby, G.; Burke, A. B.; Phytochemistry 1987, 26, 1059.

26. Gobbo-Neto, L.; Lopes, N. P.; Quim. Nova 2007, 30, 374.

27. Tjolsen, A.; Berge, O. G.; Hunskaar, S.; Rosland, J. H.; Hole, K.; Pain 1992, 51, 5.

28. Tubaro, A.; Dri, P.; Delbello, G.; Zilli, C.; Della Loggia, R.; Agents Act. 1985, 17, 347.

29. Orhan, I.; Küpeli, E.; Aslan, M.; Kartal, M.; Yesilada, E.; J. Ethnopharmacol. 2006, 105, 235.

Submitted: October 17, 2008 Published online: May 7, 2010

FAPESP has sponsored the publication of this article. 


\title{
Chemical Composition and Anti-Inflammatory Evaluation of Essential Oils from Leaves and Stem Barks from Drimys brasiliensis Miers (Winteraceae)
}

\section{João Henrique G. Lago, *,a Larissa A. C. Carvalho, ${ }^{b}$ Flávia S. da Silva, ${ }^{b}$ Daniela de O. Toyama, ${ }^{c}$ Oriana A. Fávero ${ }^{c}$ and Paulete Romoff ${ }^{b}$}

\author{
${ }^{a}$ Departamento de Ciências Exatas e da Terra, Universidade Federal de São Paulo, 09972-270 Diadema-SP, Brazil \\ ${ }^{b}$ Centro de Ciências e Humanidades and ${ }^{c}$ Centro de Ciências Biológicas e da Saúde, \\ Universidade Presbiteriana Mackenzie, 01302-907 São Paulo-SP, Brazil
}

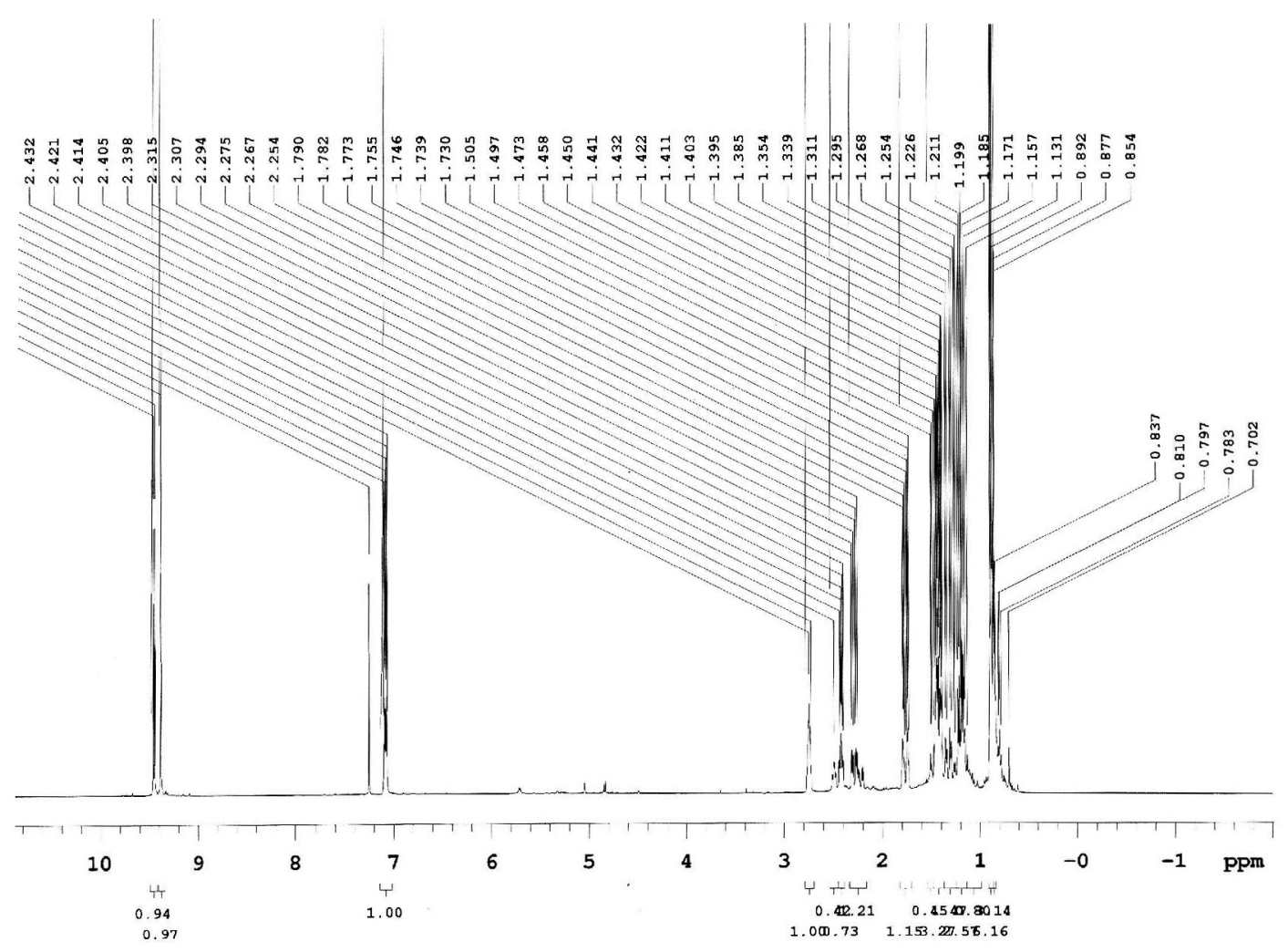

Figure S1. ${ }^{1} \mathrm{H}$ NMR spectrum of polygodial $\left(300 \mathrm{MHz}, \mathrm{CDCl}_{3}\right)$. 


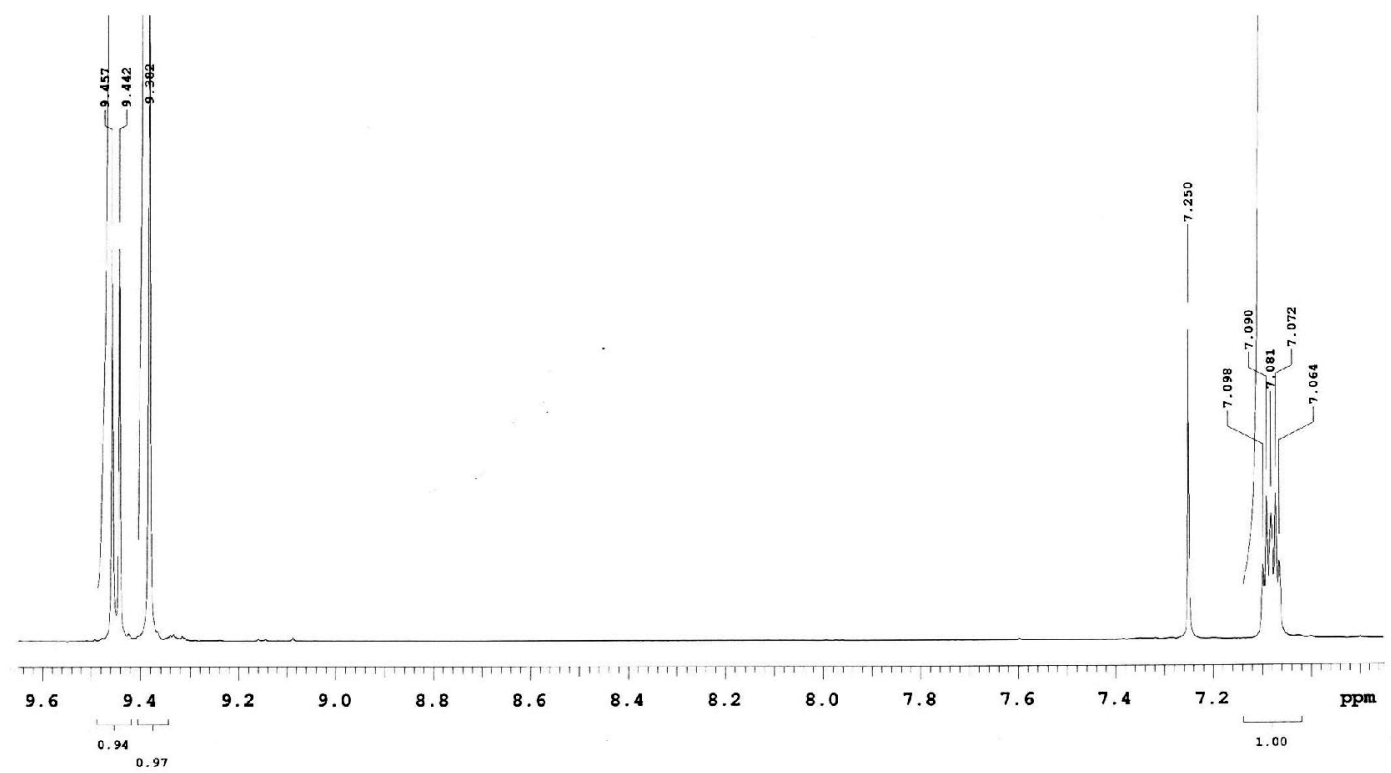

Figure S2. ${ }^{1} \mathrm{H}$ NMR spectrum of polygodial $\left(300 \mathrm{MHz}, \mathrm{CDCl}_{3}\right)$ - regions $\delta 10.0-7.0$.

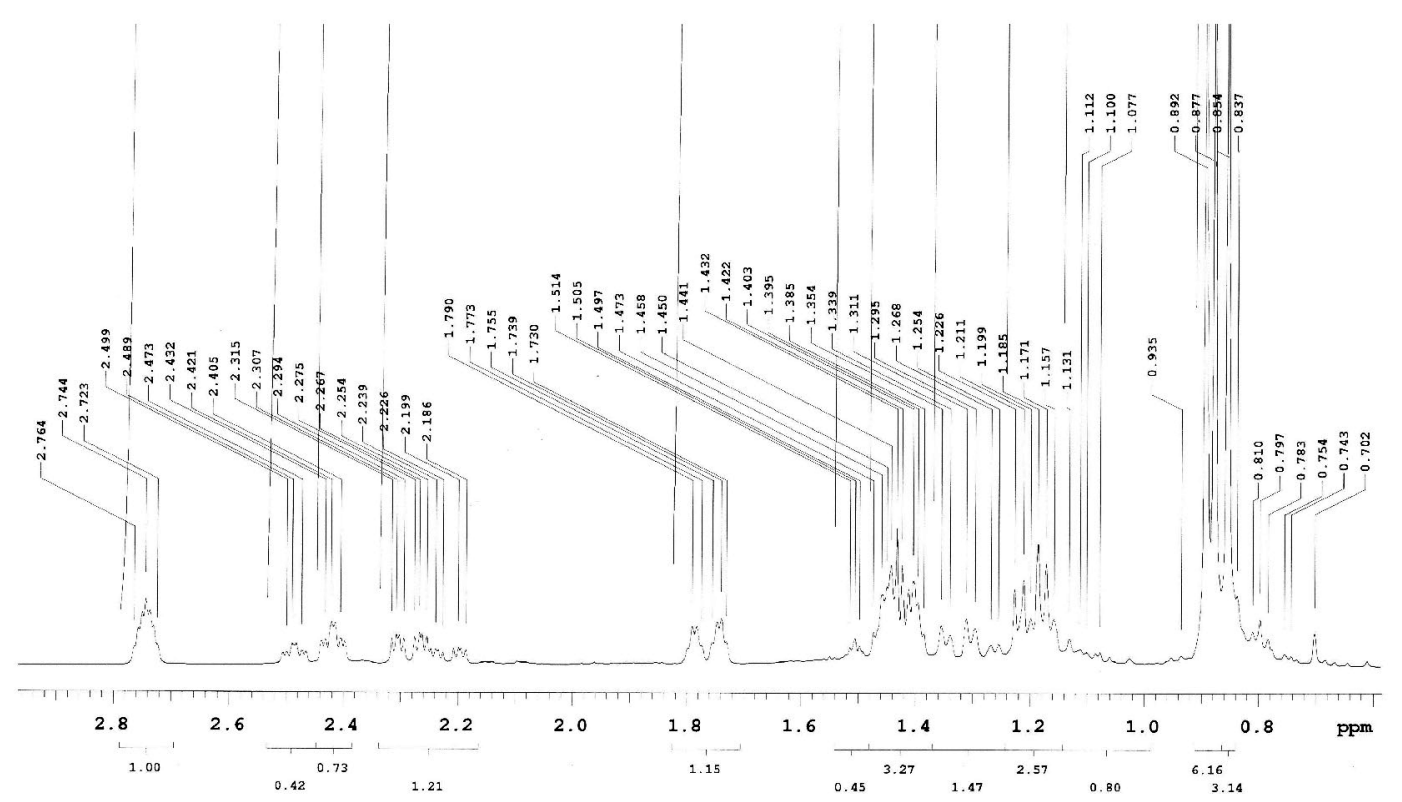

Figure S3. ${ }^{1} \mathrm{H}$ NMR spectrum of polygodial $\left(300 \mathrm{MHz}, \mathrm{CDCl}_{3}\right)-$ regions $\delta 0.0-3.0$. 


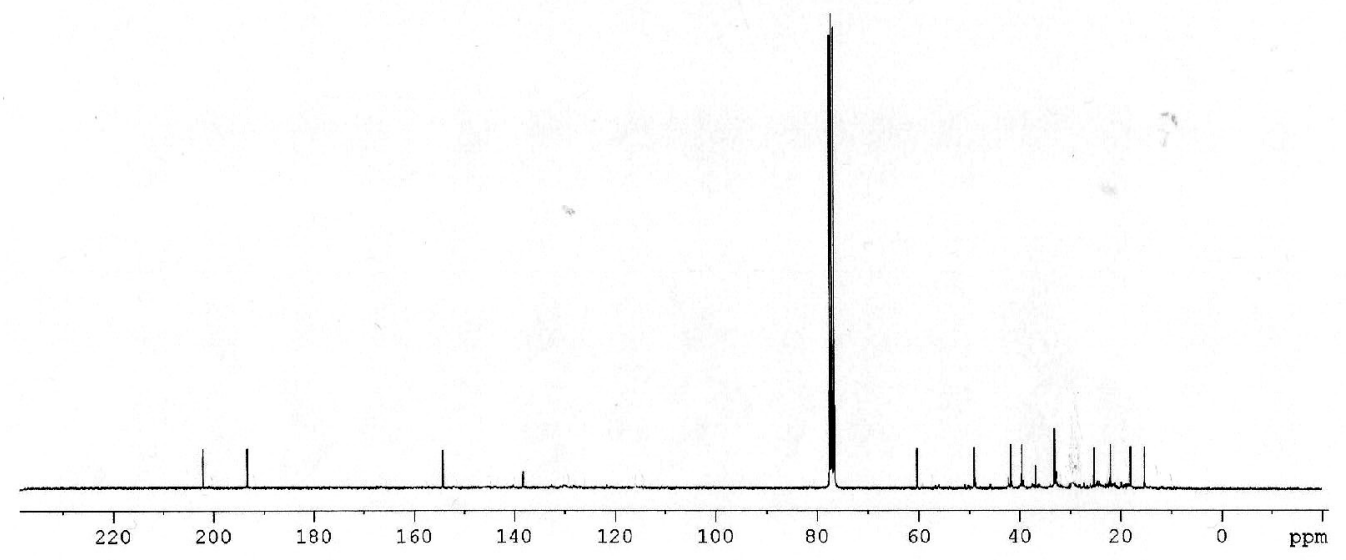

Figure S4. ${ }^{13} \mathrm{C}$ NMR spectrum of polygodial $\left(75 \mathrm{MHz}, \mathrm{CDCl}_{3}\right)$. 